\title{
Polityczne i prawne uwarunkowania uchwalenia ustawy o Sądzie Najwyższym w 1962 r.
}

\author{
SUMMARY \\ The Political and Legal Conditions of Enactment of the Act \\ Concerning the Supreme Court in 1962
}

After WW II, the Supreme Court functioned pursuant to the Law on the Organization of General Jurisdiction Courts of 1928 as a court of cassation (kasacyjny) - and after the 1949-1950 reform of the court system - as an appellate (rewizyjny) court. As a consequence of the politically-motivated appointments prevailing from the mid-1940s to mid-50s, the justices of the interwar period were replaced by new judges at the disposition of political power and executive authorities during the Stalinist period. The thaw in relations of October 1956 led to a temporary alteration of the Supreme Court's functioning and the approach developed in judicial decisions. By 1958, the direction adopted in the judicial decisions of criminal courts had already begun to raise serious doubts among the Polish United Workers' Party (PZPR). This fact spurred legislative work, which was completed with the enactment of the Act of 16 February 1962 on the Supreme Court. The Act was the first separate piece of legislation concerning the Supreme Court in the history of the People's Republic of Poland (PRL). It conformed with the 1952 Constitution of the PRL in recognizing the position of the Supreme Court as the supreme judicial authority exercising supervision over all other courts of justice as far as judicial decisions are concerned, and in establishing the principle that Supreme Court justices be elected for a 5-year term. The systemic changes of the law necessitated the election of the entire bench of the Supreme Court, which allowed for a verification of the existing justices and the election of those who guaranteed a new approach to criminal law that accorded with the expectations of the party.

Key words: Supreme Court, Polish United Workers' Party (PZPR), judiciary

Słowa kluczowe: Sąd Najwyższy, Polska Zjednoczona Partia Robotnicza (PZPR), wymiar sprawiedliwości 
Po zakończeniu II wojny światowej Sąd Najwyższy został reaktywowany $\mathrm{w}$ tymczasowej siedzibie $\mathrm{w}$ Łodzi i funkcjonował jako sąd kasacyjny na podstawie Prawa o ustroju sądów powszechnych z 1928 r. ${ }^{1}$ Organizacja wewnętrzna Sądu Najwyższego nie odbiegała znacznie od wzorca z okresu międzywojennego. Składał się on z dwóch izb: cywilnej i karnej, a przy nim funkcjonowała Izba do spraw Adwokatury.

W następstwie reformy sądowej w latach 1949-1950 Sąd Najwyższy stał się sądem rewizyjnym, dodatkowo dysponującym środkami nadzoru pozainstancyjnego, które miały służyć do kontroli orzecznictwa sądów niższych. Zmianom tym towarzyszyło przeniesienie siedziby Sądu Najwyższego do Warszawy $^{2}$ oraz likwidacja Izby do spraw Adwokatury.

Przełom Październikowy '56 wpłynął na przywrócenie właściwej roli organów kolegialnych $\mathrm{w}$ ramach wewnętrznej organizacji Sądu Najwyższego. Zmianie uległ kierunek orzecznictwa i sposób ferowania wyroków przez odejście od „kultu fikcji jednomyślności”, a także atmosfera pracy, która oddawała entuzjazm, jaki towarzyszył przełomowi politycznemu.

Niezwykle istotne znacznie dla oceny Sądu Najwyższego w oczach władz politycznych miała jego obsada, stopień upartyjnienia kadr oraz możliwość prawna i faktyczna realizacji polityki personalnej wobec korpusu sędziowskiego. Ten aspekt miał duży wpływ na rozpoczęcie prac legislacyjnych na przełomie lat pięćdziesiątych i sześćdziesiątych nad nową ustawą o Sądzie Najwyższym, który w odnowionym składzie miał być organem w pełni realizującym zadania budowy ustroju państwa dyktatury proletariatu ${ }^{3}$.

W 1945 r. - staraniem Pierwszego Prezesa Wacława Barcikowskiego do służby przywrócono prawie wszystkich żyjących sędziów Sądu Najwyższego. Skład uzupełniono osobami legitymującymi się dobrym przygotowaniem prawniczym i dużym doświadczeniem zawodowym. $Z$ uwagi na taką obsadę personalną Sądu Najwyższego, jak i sądów powszechnych niższej instancji, gdzie w większości orzekali sędziowie z okresu międzywojennego, nie cieszyły się one pełnym zaufaniem władz Polski Ludowej, co prowadziło do ograniczenia ich właściwości na rzecz sądów szczególnych i specjalnych organów quasi-sądowych. Dlatego już od końca lat czterdziestych rozpoczęto "oczyszczanie aparatu sądowego z elementów wrogich, klasowo obcych i szko-

1 Rozporządzenie Prezydenta Rzeczypospolitej z dnia 6 lutego 1928 r. - Prawo o ustroju sądów powszechnych (Dz. U. z 1928 r. Nr 12, poz. 93); Obwieszczenie MS z dnia 15 listopada 1932 r. w sprawie ogłoszenia jednolitego tekstu prawa o ustroju sądów powszechnych (Dz. U. Nr 102, poz. 863); Rozporządzenie Ministra Sprawiedliwości z dnia 3 marca 1945 r. o tymczasowej siedzibie Sądu Najwyższego (Dz. U. Nr 7, poz. 35).

2 Komunikat w sprawie przeniesienia Sądu Najwyższego od 1 maja 1950 r. do stałej siedziby w Warszawie (Dz. Urz. MS z 1950 r. Nr 3, poz. 11, s. 14).

3 Patrz szerzej A. Lityński, O praworządności „ludowej” w Polsce 1944-1956 teoretycznych uwag kilka, [w:] Z dziejów prawa, t. 1(8), Katowice 2006, s. 168. 
dliwych", stopniowo przenosząc w stan spoczynku przedstawicieli korpusu sędziowskiego z okresu międzywojennego ${ }^{4}$. Sędziowie Sądu Najwyższego, którzy nie orzekali zgodnie z oczekiwaniem władz politycznych i organów bezpieczeństwa publicznego szybko kończyli karierę $\mathrm{w}$ instancji najwyższej. $\mathrm{W}$ ich miejsce pojawiali się pochodzący z nominacji ministerialnej sędziowie, dyspozycyjni wobec dyrektyw ośrodka władzy politycznej ${ }^{5}$.

Wraz ze zmianami kadrowymi szybko wzrastał stopień upartyjnienia Sądu Najwyższego. Potwierdzeniem rosnącego zaufania wobec Sądu Najwyższego było rozszerzanie właściwości sądownictwa powszechnego, w następstwie czego na jego wokandę w Izbie Karnej (a zwłaszcza utworzonej w niej sekcji tajnej) zaczęły trafiać sprawy najpoważniejszych przestępstw z punktu widzenia ochrony interesów politycznych i gospodarczych Państwa Ludowego. $\mathrm{W}$ jej składach zasiadali sędziowie mechanicznie wydający wyroki w duchu nowego kanonu obowiązków sędziowskich wskazanych w znowelizowanym Prawie o ustroju sądów powszechnych .

Od początku lat pięćdziesiątych Sąd Najwyższy cierpiał na braki kadrowe, z uwagi na prowadzoną politykę personalną Ministerstwa Sprawiedliwości i zbyt słabą pozycję Pierwszego Prezesa Sądu Najwyższego. Nadzieję wzbudziła Konstytucja PRL, która zakładała nowe zasady wyboru sędziów Sądu Najwyższego. Niestety, po wejściu ustawy zasadniczej w życie, nie doszło do oczekiwanych zmian w zakresie polityki personalnej, a tym samym wzmocnienia potencjału Sądu Najwyższego jako najważniejszego ośrodka myśli prawniczej w kraju.

Zmiany nastąpiły dopiero w Październiku'56 i były realizowane przez nowe kierownictwo Sądu Najwyższego z Pierwszym Prezesem Janem Wasilkowskim na czele. Przeprowadzona weryfikacja orzekających sędziów oraz liczne powołania na stanowiska sędziów Sądu Najwyższego z uwzględnieniem wymogów wskazanych $\mathrm{w}$ znowelizowanym Prawie o ustroju sądów powszechnych pozwoliły na odbudowę autorytetu instancji najwyższej. Na stanowiska powrócili także ci, którzy zostali wcześniej zmuszeni do odejścia ze służby w wymiarze sprawiedliwości z uwagi na "liberalne" orzecznictwo ferowane w zbyt daleko posuniętym poczuciu niezawisłości sędziowskiej

4 I. Iserles, Polityka kadr i szkolenia pracowników wymiaru sprawiedliwości w świetle uchwał IV Plenum KC PZPR, DPP 1950, nr 6, s. 31, 33.

5 Szerzej na ten temat: A. Bereza, Sąd Najwyższy w latach 1945-1962. Organizacja i działalność, Warszawa 2012, s. 49-59.

6 Art. 2 i 3 Prawa o ustroju sądów powszechnych (obwieszczenie MS z dnia 16 sierpnia 1950 r. o ogłoszeniu jednolitego tekstu prawa o ustroju sądów powszechnych, Dz. U. Nr 39, poz. 360) dalej: PUSP (1950).

7 Szerzej na ten temat: A. Bereza, Wpływ polskiego Października'56 na organizację i funkcjonowanie Sądu Najwyższego (zarys problematyki), [w:] Społeczeństwo a władza. Ustrój, prawo, idee, red. J. Przygodzki i M. Ptak, Wrocław 2010, s. 925-934. 
Już w świetle znowelizowanego w 1950 r. Prawa o ustroju sądów powszechnych Sąd Najwyższy uzyskał status "najwyższego organu sądowego", co oczywiście pozostało w sferze deklaracji ${ }^{8}$. Realizacja idei nadzoru judykacyjnego Sądu Najwyższego nad całym wymiarem sprawiedliwości była niemożliwa z uwagi na realia polityczne czasów stalinowskich oraz istniejące nadal odrębne piony sądownictwa szczególnego'. Dlatego przygotowany w $1950 \mathrm{r}$. projekt zmian dotyczący pozycji Sądu Najwyższego, zakładający jego nadzór „nad postępowaniem sądowym we wszystkich sądach" i podporządkowanie mu pionu sądownictwa wojskowego przez utworzenie Kolegium do spraw Wojskowych Sądu Najwyższego nie wyszedł poza fazę wymiany poglądów pomiędzy Ministerstwem Sprawiedliwości i Sądem Najwyższym ${ }^{10}$.

Także uchwalona 22 lipca 1952 r. Konstytucja PRL, w art. 51 statuowała Sąd Najwyższy jako „naczelny organ sądowy sprawujący nadzór nad działalnością wszystkich innych sądów w zakresie orzekania"11. Brzmienie tego artykułu ustalono $\mathrm{w}$ trakcie prac legislacyjnych dopiero na ostatnim posiedzeniu podkomisji Wymiaru Sprawiedliwości, jako efekt kompromisu z przedstawicielami resortu sprawiedliwości. W Konstytucji PRL przewidziano utrzymanie odrębnych pionów sądownictwa szczególnego, które zgodnie z postulowaną zasadą koncentracji nadzoru sądowego powinny być podporządkowane Sądowi Najwyższemu ${ }^{12}$. Było to odwzorowanie modelu radzieckiego, a tym samym pozostawało zbieżne $\mathrm{z}$ przyjętymi już regulacjami $\mathrm{w}$ innych państwach socjalistycznych ${ }^{13}$. Do rozwiązań tych nawiązywały także wprowadzone w Konstytucji PRL nowe zasady obsady stanowisk sędziowskich w Sądzie Najwyższym, co $\mathrm{w}$ istocie stało się ważnym impulsem do podjęcia dalszych prac przygotowawczo-legislacyjnych nad ustawą o Sądzie Najwyższym.

Po wejściu w życie Konstytucji PRL pojawiły się pierwsze projekty ustaw, które zakładały wprowadzenie stanu zgodnego z postanowieniami ustawy zasadniczej. Najważniejszy z nich to projekt ustawy o ustroju Sądu Najwyższego z 1954 r. przygotowany przez sędziów Sądu Najwyższego. Zakładano w nim utworzenie trzech izb: cywilnej, karnej i wojskowej. Projekt spotkał się ze stosunkowo chłodnym, a nawet krytycznym przyjęciem w Ministerstwie

8 Art. 22 PUSP (1950).

9 Art. 1 § 3 PUSP (1950) pozostawiony w dotychczasowym brzmieniu, mimo zawartej w Małej Konstytucji z 1947 r. zasady przekazania całego wymiaru sprawiedliwości do sądów powszechnych.

10 sądów, redakcja II L.L. [t]. Leszek Lernell - A.B.], nfol.

11 W projekcie uchwalonym 23 stycznia 1952 r. przez Komisję Konstytucyjną art. 51 ust. 1 mówił o nadzorze nad działalnością wszystkich innych sądów (Konstytucja Polskiej Rzeczypospolitej Ludowej. Projekt uchwalony dnia 23.1.1952 r. przez Komisje Konstytucyjna, „Państwo i Prawo” (dalej: PiP) 1952, z. 2, s. 196), a granice tego nadzoru „w zakresie orzecznictwa” pojawiły się dopiero na dalszym etapie prac legislacyjnych.

12 Art. 46 Konstytucji PRL.

13 ARB, Wspomnienia W. Barcikowskiego z 1952 r., k. 21-22. 
Sprawiedliwości. Przyczyną było pominięcie w nim wielu dotychczasowych uprawnień ministra sprawiedliwości w stosunku do Sądu Najwyższego, które znajdowały się już we wcześniejszych projektach przygotowywanych w Departamencie Ustawodawczym Ministerstwa Sprawiedliwości ${ }^{14}$. Projekt ten nie miał więc szans, aby stać się podstawą poważnej dyskusji na temat proponowanych w nim rozwiązań. Tym samym osobliwością polskiego ustroju sądownictwa był trwający przez blisko 10 lat stan prawny sprzeczny z ustawą zasadniczą, polegający na utrzymaniu odrębnego sądownictwa szczególnego, które nie podlegało nadzorowi judykacyjnemu Sądu Najwyższego. Także obsada stanowisk sędziów Sądu Najwyższego w latach 1952-1962 odbywała się na podstawie przepisów dotychczasowych, $\mathrm{z}$ tą niewielką zmianą, że uprawnienia Prezydenta Rzeczypospolitej do powołania sędziów Sądu Najwyższego przewidziane w Prawie o ustroju sądów powszechnych przeszły na Radę Państwa z dniem dokonania jej wyboru przez Sejm PRL ${ }^{15}$.

Prace legislacyjne prowadzone $\mathrm{w}$ kierunku wzmocnienia pozycji ustrojowej Sądu Najwyższego wznowiono po Październiku '56, a ich inicjatorem był Pierwszy Prezes Sądu Najwyższego Jan Wasilkowski. O zintensyfikowaniu prac nie zadecydowały jednak kwestie natury prawnej, ale krytyczna ocena działalności Sądu Najwyższego w oczach kierownictwa PZPR pod koniec lat pięćdziesiątych. Zaniepokojenie budziła przede wszystkim działalność Izby Karnej, będąca swoistą odpowiedzią na orzecznictwo karne z czasów stalinowskich. Mimo że pojawiły się znacznie bardziej represyjne akty prawne dotyczące przestępczości gospodarczej, a także wytyczne partii dotyczące surowego karania określonych kategorii przestępstw Sąd Najwyższy nie reagował na nie w sposób, jaki był oczekiwany przez władze polityczne. Niepokojące dla władz było zbyt niezależne stanowisko sędziów Izby Karnej, tym bardziej, że stopień ich „ubezwłasnowolnienia” wytycznymi partii uległ znacznemu obniżeniu. Wpływ na taką sytuację miały niedawno jeszcze głoszone hasła Października '56 o potrzebie utrzymania niezawiłości sędziowskiej, echa trwających procesów rehabilitacyjnych jako efekt krzywd $\mathrm{z}$ okresu stalinowskiego oraz istniejący wśród sędziów "syndrom sekcji tajnej”, jako przejaw łamania praworządności ludowej ${ }^{16}$.

Już w 1958 r. zwrócono uwagę w łonie partii, że Sąd Najwyższy „zamiast być źródłem zaostrzania i przyśpieszania represji karnej, był w większości wy-

14 Archiwum Akt Nowych (dalej: AAN), Ministerstwo Sprawiedliwości (dalej: MS) 229, Projekt ustawy o ustroju SN (I Prezes SN), k. 1-7, Projekt Departamentu Ustawodawczego Ministerstwa Sprawiedliwości [b.d.], k. 9, Opinia L. Lernella z 4 marca 1954 r., k. 11; ARB, Projektu ustawy z 1950 r. o ustroju sądów, redakcja II L.L., nfol.

15 Art. 5 pkt 2 Ustawy Konstytucyjnej z dnia 22 lipca 1952 r. - Przepisy wprowadzające Konstytucję Polskiej Rzeczypospolitej Ludowej (Dz. U. Nr 33, poz. 233).

16 O sekcjach tajnych patrz: A. Lityński, Historia prawa Polski Ludowej, Warszawa 2013, s. 42-45. 
padków źródłem jej łagodzenia"17. Stworzyło to szczególny klimat dla rozpoczęcia prac nad nową regulacją dotyczącą pozycji ustrojowej Sądu Najwyższego oraz zasad wyboru jego sędziów. Celem jaki przyświecał kierownictwu PZPR (stosowną dyrektywę Biura Politycznego podjęto 19 stycznia 1959 r.) decydującym o przyśpieszeniu prac nad ustawą o Sądzie Najwyższym była konieczność pilnego "odnowienia" składu personalnego Sądu Najwyższego ${ }^{18}$.

Służyć temu miało, nabierające nagle aktualności, dostosowanie przepisów tyczących Sądu Najwyższego do pozycji ustrojowej, jaką przewidywały dla niego postanowienia Konstytucji PRL. Artykuł 51 Konstytucji wyrażał dwie niewprowadzone dotychczas w życie - zasady. Pierwsza sytuowała Sąd Najwyższy jako naczelny organ sądowy, który sprawuje nadzór nad działalnością innych sądów, a druga określała wybór Sądu Najwyższego przez Radę Państwa na 5 lat. Realizacja tych zasad mogła nastąpić jedynie w drodze uchwalenia nowej ustawy o Sądzie Najwyższym. Początkowo nie miała to być regulacja kompleksowa, gdyż dyrektywy Biura Politycznego KC PZPR nakazywały przygotowanie jedynie projektu ustawy o wyborze Sądu Najwyższego, niezależnie od ogólnej reformy sądownictwa ${ }^{19}$. Wskazuje to na główny cel zmian prawnych, jakim była konieczność przeprowadzenia zmian kadrowych w instancji najwyższej, a ich dodatkowym uzasadnieniem ideologicznym była okoliczność, iż jedynie w Polsce (i na Węgrzech) nie zrealizowano przyjętej w ZSRR i państwach bloku wschodniego zasady wyboru sędziów Sądu Najwyższego ${ }^{20}$. Decyzja dotycząca pełnej realizacji art. 51 Konstytucji PRL zapadła dopiero na posiedzeniach Komisji do spraw Wymiaru Sprawiedliwości KC PZPR, jakie odbyły się 2 października 1959 r. i 26 lipca 1960 r. Szybkość prowadzonych prac pozwalała nawet na deklaracje - chociaż w praktyce nierealne - dotyczące przygotowania projektu ustawy o Sądzie Najwyższym na jesienną sesję sejmową w $1960 \mathrm{r}^{21}$

17 M. Mazur, Z. Resich, Sąd Najwyższy w okresie XX-lecia Polski Ludowej, „Nowe Prawo” (dalej: NP) 1964, nr 7-8, s. 690; R. Walczak, Sprawowanie kierowniczej roli partii w sąach i prokuraturze w Polsce Ludowej (studium politologiczne), Warszawa 1987, s. 341-345; J. Kuciński, Ustrojowo-polityczne koncepcje PZPR w latach 1948-1959, Warszawa 1984, s. 298-299.

18 AAN, MS 409, Pismo do PZPR Z-cy Kierownika Wydziału Administracyjnego S. Marczewskiego z 20 października 1960 r., k. 49; R. Walczak, Przewodnia rola partii w sąach powszechnych $w$ Polsce Ludowej [w:] Przewodnia rola partii a niezawistość sędziowska („Biblioteka Sędziego" nr 58), Warszawa 1987, s. 60-61.

19 Nad reformą sądownictwa powszechnego i zmian jego struktury pracowano już od końca $1958 \mathrm{r}$. w łonie Komisji Kodyfikacyjnej. AAN, SN 1/154, Tezy w sprawie struktury sądów powszechnych autorstwa A. Opuszyński (k. 10-11), M. Grudziński (k. 12), J. Wasilkowski (k. 13-14), M. Mazur (k. 15-16).

20 AAN, MS 409, Notatka o strukturze i zadaniach sądów najwyższych: ZSRR i krajów demokracji ludowej z 26 sierpnia 1960 r., k. 30; A. Gorkin, Usytuowanie Sądu Najwyższego ZSRR w systemie radzieckich organów państwowych, NP 1967, nr 11, s. 1399.

21 AAN, KC PZPR LI 58, Zaproszenie Kierownika Wydziału Administracyjnego KC PZPR na posiedzenie zespołu w dniu 26 lipca 1960 r., Protokół posiedzenia Zespołu Wymiaru Sprawiedliwości z 26 lipca 1960 r., nfol. 
Wśród przyczyn prac nad nową ustawą o Sądzie Najwyższym na piedestale należy postawić uwarunkowania polityczne, cele jakie stawiano $\mathrm{w}$ gremiach politycznych, dla których hasło zachowania spójności systemu ustrojowego sądownictwa $\mathrm{z}$ ustawą zasadniczą traktowano jedynie instrumentalnie.

Prace rozpoczęto $\mathrm{w}$ zespole Komisji Kodyfikacyjnej pod przewodnictwem Jana Wasilkowskiego. W posiedzeniu, na którym opracowano założenia ustawy, uczestniczyli: sędziowie Sądu Najwyższego Aleksander Bachrach, Jerzy Jodłowski, Stanisław Gross, Marian Mazur, Zbigniew Opuszyński i Zbigniew Resich, a także Szef Kancelarii Rady Państwa Henryk Holder, Dyrektor Generalny w Urzędzie Rady Ministrów Stefan Rozmaryn, prezes Najwyższego Sądu Wojskowego Jan Mitek, delegat ministra sprawiedliwości Maurycy Herling-Grudziński i delegat ministra obrony narodowej płk Leon Łustacz ${ }^{22}$. Taki skład zespołu, w większości złożony z sędziów Sądu Najwyższego, umożliwiał prowadzenie prac, zakładających pełne urzeczywistnienie art. 51 Konstytucji PRL. Za takim kierunkiem przemawiały również prowadzone w Komisji Kodyfikacyjnej prace nad prawem o ustroju sądów oraz nowymi kodeksami postępowania sądowego.

W zespole Komisji Kodyfikacyjnej przyjęto szczegółowe zasady wyboru Sądu Najwyższego na tle ogólnej regulacji konstytucyjnej, wykorzystane później do przygotowania projektu ustawy:

- Rada Państwa wybiera Sąd Najwyższy w całości na 5 lat.

- W czasie trwania kadencji Rada Państwa dokonuje wyboru poszczególnych sędziów (na stanowiska opróżnione lub nowe) na okres do końca danej kadencji Sądu Najwyższego.

- Rada Państwa wybiera sędziów spośród kandydatów, których grono obejmuje sędziów Sądu Najwyższego kończącej się kadencji (przy pierwszym wyborze spośród obecnych sędziów Sądu Najwyższego) oraz innych osób wpisanych na listę kandydatów z własnej inicjatywy Rady Państwa lub na wniosek ministra sprawiedliwości (a także ministra obrony narodowej przy sędziach Izby Wojskowej).

- Rada Państwa dokonuje jednocześnie wyboru na stanowiska Pierwszego Prezesa, prezesów i ewentualnie przewodniczących Kolegiów Sądu Najwyższego ${ }^{23}$.

Duże kontrowersje w zespole budziła możliwość odwołania sędziów Sądu Najwyższego w czasie trwania kadencji. Część zespołu opowiadała się za moż-

22 AAN, MS 31, Notatka w sprawie realizacji art. 51 Konstytucji PRL, k. 18-19.

23 AAN, MS 31, Notatka w sprawie realizacji art. 51 Konstytucji PRL, k. 20-21, 26; MS 409, Notatka o strukturze i zadaniach sądów najwyższych: ZSRR i krajów demokracji ludowej z 26 VIII 1960 r., k. 28; B. Szmulik, Sąd Najwyższy w PRL, [w:] W kręgu nowożytnej i najnowszej historii ustroju Polski. Księga dedykowana Profesorowi Marianowi Kallasowi, red. S. Godek, D. Makiłła, M. Wilczek-Karczewska, Warszawa 2010, s. 368. 
liwością odwołania sędziego przed upływem kadencji przez Radę Państwa na wniosek ministra sprawiedliwości, gdy nie daje on rękojmi należytego wykonywania obowiązków sędziego w Polsce Ludowej. Większość jednak opowiadała się przeciwko takiemu rozwiązaniu argumentując, że powaga sędziego Sądu Najwyższego wymaga stabilności stanowiska. Podkreślano, że każda kandydatura sędziego przed wyborem będzie poddana dokładnej analizie, uwzględniającej poziom zawodowy i etyczny, dotychczasową praktykę i postawę polityczną kandydata. Natomiast w przypadkach drastycznych będzie istniała możliwość wydalenia sędziego ze służby w trybie postępowania dyscyplinarnego, zaś w innych sytuacjach można będzie dokonać wewnętrznych przesunięć w ramach podziału czynności, np. z jednej izby do drugiej, albo odsunąć takiego sędziego od orzekania kierując do Biura Orzecznictwa. Ponadto zauważano, powołując się na doświadczenia przeszłości, że jest mało prawdopodobne, aby sędzia przekonany o swojej nieprzydatności do pracy w Sądzie Najwyższym lub nieprzydatności do pełnienia w tym sądzie pewnej szczególnej funkcji, nie zgłosił dobrowolnie rezygnacji. Dyskusjom tym niewątpliwie przyświecała stale obawa o właściwy - z punktu widzenia władz politycznych - dobór sędziów Izby Karnej24.

Propozycje zespołu dotyczące szczegółowych zasady wyboru Sądu Najwyższego zostały zaakceptowane w Ministerstwie Sprawiedliwości. Natomiast Prezes Najwyższego Sądu Wojskowego sprzeciwił się projektowanemu sposobowi odnawiania składu Sądu Najwyższego, uznając je za sprzeczne z zasadą wybierania Sądu Najwyższego in corpore. W jego ocenie Rada Państwa winna dokonać wyboru Sądu Najwyższego w pełnym jego składzie na 5 lat. Natomiast $\mathrm{w}$ przypadku, gdy w czasie kadencji skład uległby zdekompletowaniu w takim rozmiarze, że uniemożliwiałoby to normalne jego funkcjonowanie, należałoby przeprowadzić nowe wybory pełnego składu Sądu Najwyższego ${ }^{25}$. Pogląd ten nie został uwzględniony i nie znalazł odzwierciedlenia w projekcie ustawy.

Znacznie trudniejsza debata toczyła się wokół rozciągnięcia nadzoru judykacyjnego Sądu Najwyższego na sądy szczególne, tj. sądy wojskowe i sądy ubezpieczeń społecznych. Rozważano różne formy nadzoru, gdyż kwestii tej nie przesądzał art. 51 Konstytucji PRL.

W przypadku sądownictwa wojskowego analizowano kilka rozwiązań, a dyskusja toczyła się wokół charakteru oraz zakresu nadzoru judykacyjnego Izby Wojskowej Sądu Najwyższego.

\footnotetext{
24 AAN, SN 1/180, Projekt notatki w sprawie realizacji art. 51 Konstytucji P.R.L., k. 3-4; SN 1/154, Notatka o wynikach pracy podzespołu w sprawie zasad powoływania i odwoływania sędziów, k. 33-34.

25 AAN, MS 409, Prezes NSW do St. Marczewskiego Zastępcy Kierownika Wydziału Administracyjnego KC PZPR z 20 X 1960 r., k. 49.
} 
Początkowo istniały dwa rozwiązania organizacyjne ${ }^{26}$ :

- Najwyższy Sąd Wojskowy zostałby wcielony do Sądu Najwyższego jako jedna $\mathrm{z}$ jego Izb. To rozwiązanie było najprostsze, gdyż nie pociągało żadnych kosztów reorganizacyjnych. Zagrożenie widziano jedynie ze strony funkcjonalnej, gdyż do Sądu Najwyższego przeszłyby sprawy niewielkiej wagi rozstrzygane dotychczas przez Najwyższy Sąd Wojskowy, wykonujący funkcję sądu II instancji we wszystkich sprawach rozstrzyganych przez sądy wojskowe (okręgowe i garnizonowe) ${ }^{27}$. Za takim rozwiązaniem opowiadał się Prezes Najwyższego Sądu Wojskowego, co oznaczało rezygnację z pierwszych wyborów sędziów Izby Wojskowej, pozostawiając tę kwestię do rozwiązania w okresie późniejszym.

- Najwyższy Sąd Wojskowy zostałby utrzymany jako Trybunał Wojskowy rozstrzygający w II instancji większość spraw wojskowych oraz w I instancji sprawy poważniejsze, dla których II instancję stanowiłby Sąd Najwyższy. Dla tej kategorii spraw rozpoznawanych w drodze rewizji, jak i dla sprawowania nadzoru nad całym orzecznictwem $\mathrm{w}$ drodze rewizji nadzwyczajnych i uchwał zakładano utworzenie w Sądzie Najwyższym Kolegium dla spraw sądownictwa wojskowego ${ }^{28}$.

W trakcie dyskusji pojawiła się trzecia, kompromisowa, propozycja, zakładająca przejście Najwyższego Sądu Wojskowego do Sądu Najwyższego jako Kolegium dla spraw sądownictwa wojskowego (Izba Wojskowa) z ograniczonym zakresem zwykłego nadzoru judykacyjnego, ale z pełnym zakresem nadzoru pozainstancyjnego. Wiązały się z tym plany reorganizacji całego pionu sądownictwa wojskowego. W celu realizacji tej koncepcji wojskowe sądy okręgowe, oprócz spraw rozstrzyganych w I instancji, stałyby się także instancją rewizyjną dla sądów garnizonowych. Ta właśnie propozyja, nawiązująca do rozwiązań radzieckich, została ostatecznie przyjęta przez zespół, z zastrzeżeniem konieczności przeprowadzenia wyboru sędziów Kolegium dla spraw wojskowych (Izby Wojskowej) ${ }^{29}$. W podobnym kierunku rozwiązań strukturalnych

26 AAN, SN 1/154, Zakres nadzoru SN z 30 września 1958 r. (Z. Resich), s. 62; Uwagi koreferenta do referatu prezesa Resicha o zakresie nadzoru SN (S. Ehrlicha), k. 17 oraz powołana tam opinia w sprawie ustroju sądów wojskowych płk. Kryspina Mioduskiego z 15 lutego 1958 r.

Zwracano uwagę, że Izba Wojskowa będzie zmuszona do rozpoznania bardzo dużej ilości spraw w trybie odwoławczym (ponad 45\% wszystkich rozpoznawanych przez sądy garnizonowe, okręgowe i Marynarki Wojennej), które nie będą zawierały trudnych problemów prawniczych. Szerzej na ten temat: S. Guzy, O potrzebie zmian w organizacji sądownictwa wojskowego (Artykuł dyskusyjny), "Wojskowy Przegląd Prawniczy" (dalej: WPP) 1962, nr 1, s. 8, 10-12; S. Mendyka, Głos w dyskusji nad potrzeba reformy ustroju sądownictwa wojskowego, WPP 1962, nr 2, s. 156-158; Nieco inaczej: J. Polan-Haraschin, W sprawie zmian organizacyjnych w sądownictwie wojskowym (Głos w dyskusji), WPP 1962, nr 1, s. 15. 
poszły propozycje Ministerstwa Sprawiedliwości, w których jednak zakładano pozostawienie dla Kolegium dla spraw wojskowych jedynie środków nadzoru pozainstancyjnego oraz podejmowania uchwał i ustalania wytycznych ${ }^{30}$.

Dyskusja dotycząca nadzoru nad pionem sądownictwa ubezpieczeń społecznych była znacznie spokojniejsza, gdyż zakładano, że pion ten ma pozostać nienaruszony ${ }^{31}$. Trybunał Ubezpieczeń Społecznych miał pozostać sądem odwoławczym dla większości spraw, ale w sprawach ważniejszych rozstrzygałby w I instancji. W tych sprawach rewizja przysługiwałaby do Kolegium do spraw ubezpieczeń społecznych - Izby Społecznej - funkcjonującej przy Sądzie Najwyższym, która miała także czuwać nad jednolitością orzecznictwa sądów ubezpieczeń społecznych poprzez uchwalanie wytycznych. Dopuszczano także koncepcję pozostawienia dla Kolegium jedynie rozpoznawania środków nadzoru pozainstancyjnego. Obok takiego rozwiązania strukturalnego pojawiła się również wizja włączenia całego Trybunału Ubezpieczeń Społecznych do Sądu Najwyższego jako Izby Społecznej ${ }^{32}$.

Postulat wyodrębnienia Izby Społecznej był - w ocenie zespołu - konieczny, z uwagi na charakter i duży stopień zawiłości (także ze względu na ilość rozbudowanych przepisów) spraw rozpoznawanych przez pion sądów ubezpieczeń społecznych. Pojawiały się $\mathrm{w}$ zespole odosobnione głosy tych, którzy uważali to za zbędne i tworzące sztuczny podział, gdyż sprawy te może załatwiać odrębna sekcja w ramach Izby Cywilnej ${ }^{33}$.

Koncepcje dotyczące rozbudowania nadzoru Sądu Najwyższego na piony sądownictwa specjalnego były związane ze zmianami w strukturze organizacyjnej, w postaci utworzenia - obok istniejącej Izby Cywilnej i Karnej - Izby Wojskowej (Kolegium dla spraw sądownictwa wojskowego) i Izby Społecznej (Kolegium do spraw ubezpieczeń społecznych) ${ }^{34}$. Ograniczony zakres nadzoru judykacyjnego nowych struktur pozwalał planować ich niewielką obsadę. Uważano, że wystarczająca dla Izby Wojskowej będzie obsada około 10, zaś dla Izby Społecznej - 7-9 sędziów ${ }^{35}$.

czewskiego Zastępcy Kierownika Wydziału Administracyjnego KC PZPR z 20 października 1960 r., k. 49; S. Guzy, op. cit., s. 9-10. Podobne propozycje pojawiały się także później od połowy lat 60 . AAN SN 1/132, Protokoły z posiedzeń Prezydium SN na rok 1967-1968, k. 77.

AAN, MS 409, M. Rybicki do Ryszarda Strzeleckiego Sekretarza KC PZPR, k. 19.

AAN, KC PZPR LI 58, Protokół posiedzenia Zespołu Wymiaru Sprawiedliwości z 26 lipca 1960 r., nfol.

AAN, MS 31, Notatka w sprawie realizacji art. 51 Konstytucji PRL, k. 27-28.

AAN SN 1/154, Uwagi koreferenta do referatu prezesa Resicha o zakresie nadzoru Sądu Najwyższego (S. Ehrlicha), k. 17; Zakres nadzoru Sądu Najwyższego (Z. Resich), k. 62-63; SN 1/199, Projektowana struktura SN, k. 70 .

W projektach przewidziano nawet wprowadzenie nowej numeracji izb: I Izba Karna, II Izba Wojskowa, III Izba Cywilna i IV Izba Społeczna.

AAN, SN 1/199, Projektowana struktura Sądu Najwyższego, k. 70; SN 1/180, Projekt notatki w sprawie realizacji art. 51 Konstytucji P.R.L., k. 9. 
Zwraca uwagę okoliczność, że przedstawiane koncepcje nie przewidywały w ogóle utworzenia Izby Administracyjnej Sądu Najwyższego przedstawianej jeszcze w 1959 r. przez Zbigniewa Resicha, z uwagi na brak akceptacji najwyższych władz politycznych ${ }^{36}$. Nie znalazły również uznania zgłaszane projekty utworzenia w Sądzie Najwyższym Izby Gospodarczej i Izby Morskiej (Kolegium do spraw morskich ${ }^{37}$.

Zwyczaj odwzorowywania rozwiązań radzieckich na gruncie polskim spowodował, iż pojawiły się sygnały o możliwości przekazania Sądowi Najwyższemu pełnego nadzoru nad całym sądownictwem, co prowadziłoby do znacznego ograniczenia kompetencji Ministerstwa Sprawiedliwości ${ }^{38}$. Plan ten nie miał szans na pełną realizację, ale zakładano w projekcie wyjęcie Sądu Najwyższego spod nadzoru ministra sprawiedliwości i stworzenie z niego samodzielnego organu ( $w$ znaczeniu administracyjnym i budżetowym) podporządkowanego jedynie Radzie Państwa. Przeciwko takiemu rozwiązaniu występowało Ministerstwo Sprawiedliwości, gdyż oznaczało ono znaczne osłabienie pozycji ministra, w zakresie kreowania linii orzecznictwa sądowego, którego kierunek miał - od momentu uchwalenia ustawy - nadawać Sąd Najwyższy. Minister sprawiedliwości Marian Rybicki zaznaczał, że zamysł ten wykracza poza granice reformy wytyczone przez kierownictwo partyjne. Oznaczało to konfrontację z Janem Wasilkowskim, z której Pierwszy Prezes wyszedł zwycięsko. W związku z tym minister sprawiedliwości zaznaczył, że sprawą kluczową - przy przyjęciu zaproponowanego modelu Sądu Najwyższego - jest zabezpieczenie „najmocniejszej obsady politycznej stanowisk w Sądzie Najwyższym oraz w Biurze Orzecznictwa", które miało faktycznie przejąć część zadań Departamentu Nadzoru Sądowego Ministerstwa Sprawiedliwości ${ }^{39}$.

Przygotowany przez zespół Komisji Kodyfikacyjnej projekt został przekazany do ministra sprawiedliwości i prokuratora generalnego PRL w celu zajęcia stanowiska. Dopiero po wysłuchaniu ich opinii i wnikliwej analizie najwyższego kierownictwa politycznego uzyskał on akceptację ze strony Biura

36 AAN, SN 1/154, Zakres nadzoru Sądu Najwyższego (Z. Resich), k. 64; P. Fiedorczyk, Dylematy socjalistycznego kodyfikatora. Dokument archiwalny o pracach Komisji Kodyfikacyjnej w latach 1956-1958, „Miscellanea Historico-Iuridica”, t. VIII, 2009, s. 262 i 266 (przedruk: AAN, MS 545, Przewodniczący Komisji Kodyfikacyjnej przy MS Jan Wasilkowski do wiceministra sprawiedliwości Stanisława Walczaka z 24 VI 1958 r., k. 41-47).

Z. Resich, Ustawa o Sądzie Najwyższym, PiP 1962, z. 5-6, s. 774-775; AAN, SN 1/154, Zakres nadzoru Sądu Najwyższego (Z. Resich), k. 63-64; B. Szmulik, Sąd Najwyższy..., s. 366. Projekt utworzenia Izby Gospodarczej powróci z chwilą pojawienia się koncepcji przekazania spraw gospodarczych do sądownictwa powszechnego. T. Ereciński, Aktualne problemy ustroju sądownictwa, PiP 1981, z. 5, s. 23.

Ministerstwo Sprawiedliwości ZSRR zostało zniesione w 1956 r. Model taki wprowadzono w Czechosłowacji. AAN, MS 409, Notatka o strukturze i zadaniach sądów najwyższych: ZSRR i krajów demokracji ludowej z 26 sierpnia 1960 r., k. 29. 
Politycznego KC PZPR, a następnie 29 listopada 1961 r. został zatwierdzony uchwałą Rady Państwa ${ }^{40}$. W ówczesnych realiach państwowych przesądzało to o jego uchwaleniu, jeszcze przed rozpoczęciem trybu ustawodawczego.

Przygotowany projekt ustawy o Sądzie Najwyższym został wniesiony pod obrady Sejmu III kadencji ze wspólnej inicjatywy Rady Państwa i Rady Ministrów. Pierwsze czytanie projektu (druk sejmowy nr 46) odbyło się na 5 posiedzeniu Sejmu 1 grudnia 1961 r. Założenia projektu z upoważnienia wnioskodawców przedstawiał sekretarz Rady Państwa Julian Horodecki. W czasie wystąpienia podkreślał cel projektu, jakim była realizacja postanowień Konstytucji PRL dotyczących pozycji Sądu Najwyższego jako naczelnego organu sądowego, co prowadzić ma do przekształcenia całego "dotychczasowego systemu sądowego, wiążąc go przez Sąd Najwyższy w jednolitą całość". Projekt przewidywał realizację konstytucyjnej zasady wybieralności sędziów Sądu Najwyższego i podział Sądu Najwyższego na 4 izby: Cywilną, Karną, Wojskową i Ubezpieczeń Społecznych. W przestawionym projekcie zwyciężyła koncepcja możliwości odwołania sędziego przed upływem kadencji, jeżeli nie będzie on dawał rękojmi należytego wykonywania obowiązków sędziego Sądu Najwyższego. Referent, przedstawiając zalety projektu i zadania Sądu Najwyższego, uwypuklił w części swojego wystąpienia funkcję sygnalizacyjną Sądu Najwyższego mającą na "celu umacnianie praworządności w działalności nie tylko sądów, ale również innych organów państwowych i społecznych." Następnie Prezydium Sejmu, wobec braku sprzeciwu przekazało projekt ustawy do Komisji Wymiaru Sprawiedliwości ${ }^{41}$.

Pierwsze posiedzenie Komisji Wymiaru Sprawiedliwości odbyło się 19 grudnia 1961 r. pod przewodnictwem posła Jerzego Jodłowskiego. Referentem projektu ustawy był poseł Jan Wasilkowski - Pierwszy Prezes Sądu Najwyższego. W obradach - oprócz członków komisji - wzięli udział: sekretarz Rady Państwa Julian Horodecki, minister sprawiedliwości Marian Rybicki, prokurator generalny PRL Kazimierz Kosztirko, wiceminister obrony narodowej gen. dyw. Zygmunt Duszyński, szef Kancelarii Rady Państwa Henryk Holder, dyrektor generalny w Urzędzie Rady Ministrów Stefan Rozmaryn, prezes Izby Karnej Sądu Najwyższego Zygmunt Opuszyński, prezes Izby Cywilnej Sądu Najwyższego Zbigniew Resich, Naczelny Prokurator Wojskowy gen. bryg. Marian Ryba, prezes Najwyższego Sądu Wojskowego Jan Mitek i prezes Zarządu Głównego Zrzeszenia Prawników Polskich Marian Mazur. Referent w trakcie posiedzenia udzielił wyjaśnień w związku z pytaniami posłów Jana Sera-

40 AAN, MS 32, Notatka Ministra Rybickiego po konsultacjach z Ministrem Walczakiem i Dyrektorem Bafią z maja 1961, k. 14-15; projekt ustawy o SN z uzasadnieniem z 30 grudnia 1961 r., k. 1, 11; MS 409, Zestawienie uwag do projektu ustawy o Sądzie Najwyższym, s. 41; T. Sypniewski, Rada Państwa w systemie organów władzy państwowej Polski Ludowej (1947-1989), Toruń 2010, s. 311.

41 Sprawozdanie stenograficzne z 5. posiedzenia Sejmu PRL w dniu 1 grudnia 1961 r. Kadencja III Sesja II, Warszawa 1961, s. 30-33. 
fina (SD), Stanisława Stommy („Znak”), Jana Polskiego (PZPR) i Tadeusza Rześniowieckiego (ZSL). Główny nurt dyskusji dotyczył precyzyjnego określenia uprawnień ministra sprawiedliwości umożliwiających wgląd w tok czynności Sądu Najwyższego, a które nie naruszałyby niezależnej pozycji ustrojowej Sądu Najwyższego ${ }^{42}$.

W trakcie obrad minister sprawiedliwości Marian Rybicki zgłosił dwie ważne autopoprawki do projektu ustawy. Pierwsza dotyczyła przekształcenia Izby Ubezpieczeń Społecznych w Izbę Pracy i Ubezpieczeń Społecznych, do której należałby także nadzór nad sprawami wynikającymi ze stosunku pracy. Druga dotyczyła procedury wyborów sędziów Sądu Najwyższego określanej przez Radę Państwa, która miała również ustalać liczbę prezesów i sędziów Sądu Najwyższego. Zgłoszono także dużo - jak na ówczesne warunki - uwag, wskazując na brak uzgodnionych stanowisk lub ich zmianę w ostatniej chwili. W literaturze pojawiały się później sygnały, iż taka sytuacja była efektem braku szerszej publicznej debaty z udziałem prawników, którzy mogli zgłosić wcześniej swoje spostrzeżenia ${ }^{43}$.

Zgłoszone uwagi wymagały opracowania poprawek do projektu ustawy. W tym celu Komisja Wymiaru Sprawiedliwości powołała podkomisję. W jej skład weszli: Jerzy Jodłowski (SD), Tadeusz Makowski (ZSL), Bronisław Ostapczuk (PZPR), Stanisław Tomaszewski (PZPR) i Jan Wasilkowski (PZPR) ${ }^{44}$.

W czasie posiedzenia podkomisji zaakceptowano utworzenie Izby Pracy i Ubezpieczeń Społecznych Sądu Najwyższego z proponowanym zakresem właściwości. $\mathrm{W}$ ramach przegłosowanych poprawek precyzyjnie określono uprawnienia ministra sprawiedliwości do reagowania na zauważone uchybienia $w$ toku postępowania oraz uprawnienia ministra obrony narodowej wglądu w działalność Izby Wojskowej. Dyskusję rozbudziła obligatoryjność odwołania ze stanowiska sędziego Sądu Najwyższego po ukończeniu przez niego 70 lat życia. Większość stała na stanowisku ustawowego uregulowania tej kwestii, gdyż pozostawienie jej do swobodnego uznania organów państwowych mogłoby u osób odwoływanych $\mathrm{w}$ tego powodu wywołać poczucie krzywdy. Pozostałe zmiany nie budziły większych emocji ${ }^{45}$. Sprawozdanie ze swoich prac podkomisja przedstawiła na następnym posiedzeniu Komisji 5 stycznia $1962 \mathrm{r}$.

42 Biuro Sejmu, Wydział Prasowy, Biuletyn Nr 133 Komisja Wymiaru Sprawiedliwości z 19 grudnia 1961 r., s. 1-3.

43 Ibidem. Patrz także: T. Leśko, Uwagi na tle ustawy o Sądzie Najwyższym (głos w dyskusji), WPP 1962, nr 2, s. 160.

44 W obradach podkomisji uczestniczyły także te same osoby co na posiedzeniu komisji 19 grudnia 1961 r., z tą różnicą, że ministra sprawiedliwości reprezentował podsekretarz stanu Stanisław Walczak oraz nie pojawił się Prokuratur Generalny PRL i Naczelny Prokurator Wojskowy.

45 Dotyczyły one wprowadzenia delegacji dla Rady Państwa do uregulowania sprawy zaszeregowań i płac sędziów pracujących w Sądzie Najwyższym, a także uściślenia przepisów ustawy i ujednolicenia terminologii z przyjętą $\mathrm{w}$ innych aktach prawnych. 
Uwzględniając propozycje poselskie i zgłoszone autopoprawki, podkomisja zaproponowała wniesienie do projektu ustawy aż 31 poprawek, z których wiele miało znaczenie merytoryczne ${ }^{46}$.

Sprawozdanie Komisji Wymiaru Sprawiedliwości o przedłożonym projekcie ustawy o Sądzie Najwyższym wraz z wnioskiem o uchwalenie projektu z wprowadzonymi poprawkami zostało przedstawione przez sprawozdawcę posła Jana Wasilkowskiego na posiedzeniu sejmowym 15 lutego 1962 r. (druki sejmowe 46 i 52). Zaprezentował on także kontrowersje, jakie pojawiły się w łonie Komisji, dotyczące obligatoryjnego odwołania sędziego Sądu Najwyższego, który ukończył 70 lat. Wynik dyskusji doprowadził do przyjęcia stanowiska opowiadającego się za pozostawieniem tego przepisu ${ }^{47}$.

Wniosek sprawozdawcy $\mathrm{w}$ imieniu klubu poselskiego PZPR poparł poseł Stanisław Tomaszewski, kładąc nacisk na konieczność utworzenia Izby Pracy i Ubezpieczeń Społecznych w Sądzie Najwyższym. Argumentował koniecznością ujednolicenia wykładni w sferze stosunków pracowniczych, które uregulowane były $\mathrm{w}$ licznych przepisach prawa pracy rozrzuconych $\mathrm{w}$ dużej ilości aktów prawnych różnego rzędu i kształtowanych dodatkowo przez układy zbiorowe, co nastręczało trudności $\mathrm{w}$ praktycznym, prawidłowym ich stosowaniu. Zwrócił uwagę, że działalność zakładowych komisji rozjemczych, rozstrzygających spory ze stosunku pracy między pracownikami przedsiębiorstw a przedsiębiorstwami, opierała się - z uwagi na ich powiązanie ze związkami zawodowymi - na wyjaśnieniach i pismach okólnych Centralnej Rady Związków Zawodowych. Wytyczne te były najczęściej zbieżne z poglądami wyrażanymi w orzecznictwie Sądu Najwyższego, ale pojawiały się niekiedy rozbieżności ${ }^{48}$. Zdaniem posła Stanisława Tomaszewskiego można takich sytuacji uniknąć przez powołanie Izby Pracy i Ubezpieczeń Społecznych, która będzie m.in. sprawować nadzór pozainstancyjny nad działalnością zakładowych komisji rozjemczych ${ }^{49}$. W podobnym duchu wypowiadał się poseł Tadeusz Makowski w imieniu klubu poselskiego ZSL. W jego wystąpieniu pojawiła się kwestia - poruszana na etapie dyskusji nad projektem - powołania Izby Administracyjnej w Sądzie Najwyższym, lecz poseł uznał takie rozwiązanie za przedwczesne i przekraczające zakres planowanej reformy. Ponadto uznał, iż

46 Biuro Sejmu, Wydział Prasowy, Biuletyn Nr 137/III kad. Komisja Wymiaru Sprawiedliwości z 5 stycznia 1962 r., s. 1-4; L. Garlicki, Sąd Najwyższy a naczelne organy władzy państwowej w PRL, Warszawa 1977, s. 51. Sprawozdanie stenograficzne z 9 posiedzenia Sejmu PRL z dnia 15 lutego 1962 r., Warszawa 1962, 1. 7-14.

Na przykład zagadnienie dopuszczalności poszukiwania przez pracownika w trybie spornym należności przypadającej z tytułu podziału przeznaczonej na nagrody części funduszu zakładowego w przedsiębiorstwa państwowych. Wyjaśnienia Centrali Rady Związków Zawodowych i stanowisko Prokuratora Generalnego PRL w wypadku takich skarg składanych w trybie art. 13 dekretu o zakładowych komisjach rozjemczych rozstrzygały, że sprawy tego typu nie są sprawami ze stosunku pracy. Inne stanowisko zajmował natomiast Sąd Najwyższy i sądy powszechne. 
proponowane $\mathrm{w}$ środowisku prawniczym wprowadzenia dłuższej kadencji sędziów Sądu Najwyższego (np. 10 lat), są nie do przyjęcia w świetle brzmienia art. 51 Konstytucji PRL. Żywił nadzieję - podobnie jak przemawiający później w imieniu klubu poselskiego SD poseł Michał Grendys - że wcześniejsze zmiany procedury karnej i przeprowadzane zmiany procedury cywilnej pozwolą Sądowi Najwyższemu zająć się w szerszym zakresie nadzorem pozainstancyjnym ${ }^{50}$.

Niewielką dozę krytyki zawierało jedynie wystąpienie posła Stanisława Stommy w imieniu koła posłów katolickich „Znak”, który podważał zasadność (proponując nawet rewizję konstytucji) wprowadzenia 5-letniej kadencji sędziów Sądu Najwyższego z punktu widzenia stabilności stanowiska oraz możliwości odwołania sędziego Sądu Najwyższego, gdy nie daje on rękojmi należytego pełnienia funkcji. W jego ocenie niewłaściwym środkiem prawnym były także wytyczne wymiaru sprawiedliwości, przy ustalaniu których Sąd Najwyższy staje ,jak gdyby - w pewnej mierze ustawodawcą"51. Mimo zgłoszonych uwag, przeważały w jego wypowiedzi akcenty pozytywne, co znalazło odzwierciedlenie w jednogłośnym uchwaleniu w dniu 15 lutego 1962 r. ustawy o Sądzie Najwyższym ${ }^{52}$.

Ustawa, będąca pierwszym w historii Polski Ludowej odrębnym aktem dotyczącym Sądu Najwyższego, nie regulowała wszelkich aspektów związanych z jego działalnością. Uchylała ona przepisy Prawa o ustroju sądów powszechnych, które dotyczyły bezpośrednio Sądu Najwyższego. W niektórych sprawach ustawa dopuszczała odpowiednie stosowanie przepisów Prawa o ustroju sądów powszechnych, a także (w stosunku do zakresu i trybu działania Izby Wojskowej) Prawa o ustroju sądów wojskowych, o ile nie były one sprzeczne z przepisami niniejszej ustawy ${ }^{53}$.

Przyjęty model Sądu Najwyższego był rozwiązaniem oryginalnym, odbiegającym od wzorców z innych państw. Różnice dotyczyły nie tylko stawianych przed Sądem Najwyższym zadań, ale i jego umiejscowienia w systemie funkcjonowania organów władzy państwowej. Przyjęta koncepcja, chociaż niepozbawiona wad, była wyważona $\mathrm{w}$ realiach ówczesnego państwa socjalistycznego. Przyjęto dominującą w państwach bloku wschodniego zasadę wyboru sędziów Sądu Najwyższego, lecz nie przekazano tej kompetencji Sejmowi. Zrezygnowano także z wyposażenie Sądu Najwyższego w prawo inicjatywy ustawodawczej, jak i powierzenia mu pełnego nadzoru (administracyjnego i judy-

50 Ibidem, 1. 20-22, 26-27, 29.

51 Ibidem, ł.31, 33-34. Porównaj: Z. Wasilkowska, O potrzebie i kierunkach zmian przepisów o Sądzie Najwyższym, NP 1981, nr 4, s. 58-59, 62.

52 Ustawa o Sądzie Najwyższym z 15 lutego 1962 r. (Dz. U. Nr 11, poz. 54) - dalej: ustawa o Sądzie Najwyższym z 1962 r.

53 Art. 40 ust. 1 ustawy o Sądzie Najwyższym z 1962 r. 
kacyjnego) nad sądami niższymi. Sąd Najwyższy miał spełniać przede wszystkim rolę organu sądowego, nie uczestnicząc w życiu politycznym. Szeroki nadzór judykacyjny czyniący z Sądu Najwyższego sąd w zakresie prawa i faktu, odróżniały go od rozwiązań przyjętych $w$ demokracjach zachodnich, gdzie sąd najwyższej instancji pełnił głównie rolę sądu kasacyjnego (model francuski i niemiecki) $)^{54}$.

Sąd Najwyższy w świetle ustawy był naczelnym organem sądowym sprawującym nadzór na działalnością sądów powszechnych i szczególnych w zakresie orzekania ${ }^{55}$. W systemie ustrojowym PRL-u, Sąd Najwyższy jako samodzielny organ naczelny został podporządkowany naczelnym organom władzy państwowej tj. Sejmowi i Radzie Państwa. Znajdowało to uzasadnienie doktrynalne w przyjmowanej ówcześnie zasadzie jedności władzy państwowej, która miała być jakoby realizowana z poszanowaniem niezawisłości sędziowskiej ${ }^{56}$. Podległość Sejmowi była raczej teoretyczna i wynikała głównie z jego uprawnień ustawodawczych. $Z$ uwagi na prawo uchwalania budżetu przez Sejm, a co za tym idzie kontroli jego wykonania, Pierwszy Prezes Sądu Najwyższego składał sprawozdanie z jego wykonania oraz udzielał informacji związanych z rozpatrywaniem projektu budżetu. Inne uprawnienia Sejmu, jego organów i posłów uległy znacznemu ograniczeniu wobec braku podstawy prawnej takich działań oraz domniemania kompetencji zwierzchnich, jakie przysługiwały Radzie Państwa wobec Sądu Najwyższego ${ }^{57}$. Rada Państwa decydowała o obsadzie personalnej kierownictwa i stanowisk sędziowskich. Wyrażała zgodę na przejście sędziego Izby Wojskowej do innej izby Sądu Najwyższego. Odwoływała sędziów Sądu Najwyższego w czasie trwania kadencji i rozpatrywała wyroki orzekające poważniejsze kary dyscyplinarne (a więc inne niż upomnienie i nagana) wobec sędziów Sądu Najwyższego. Ustalała wielkość obsady etatowej, tabele stanowisk i grup uposażenia zasadniczego, zasady przyznawania dodatków do uposażenia sędziów i pracowników Sądu Najwyższego oraz normowała jego organizację przez uchwalenie Regulaminu Sądu Najwyższego ${ }^{58}$.

54 AAN SN 1/181, Pierwszy Prezes SN do Ministra Holdera z 27 kwietnia 1960 r., k. 158-158v; MS 409, Notatka o strukturze i zadaniach sądów najwyższych: ZSRR i krajów demokracji ludowej z 26 sierpnia 1960 r., k. 28-34; L. Garlicki, M. Rybicki, Ustrój sądów w europejskich państwach socjalistycznych, Warszawa 1976, s. 10, 13, 21, 25; S. Kotowski, K. Piasecki, Sądy Najwyższe państw socjalistycznych, Warszawa 1988, maszynopis, s. 83, 85, 87-88.

Art. 1 ustawy o Sądzie Najwyższym z 1962 r.

56 Z. Resich, Pozycja Sąu Najwyższego w PRL, NP 1969, nr 4, s. 517.

57 L. Garlicki, Z. Resich, M. Rybicki, S. Włodyka, Sąd Najwyższy w PRL, Wrocław 1983, s. 68-72; L. Garlicki, Sejm a Sąd Najwyższy (Uwwagi de lege lata i de lege ferenda), PiP 1972, nr 8-9, s. 99-103.

58 Art. 3 ust. 2, 15, 16, 17 ust. 2, 18, 20, 38, 47 ustawy o Sądzie Najwyższym z 1962 r.; Nad ustawa o Sądzie Najwyższym (dyskusja w Komitecie Nauk Prawnych PAN nad referatem członka PAN, prof. dr. Jana Wasilkowskiego), (oprac. J. Lapierre), NP 1962, nr 5, s. 605, 607-608, 612; L. Garlicki, Sąd Najwyższy a naczelne organy władzy państwowej w PRL..., s. 30, 53-56, 61, 64, 77; S. Włodyka, Funkcje Sądu Najwyższego, "Zeszyty Naukowe UJ” 1965, z. 31, s. 26; Uchwała Rady Państwa z 22 maja 1962 r. w sprawie regulaminu Sądu Najwyższego (M. P. Nr 45, poz. 210). 
Zmiana pozycji ustrojowej Sądu Najwyższego nie oznaczała jego pełnej samodzielności i niezależności od resortu sprawiedliwości, chociaż formalnie przestał podlegać naczelnemu nadzorowi ministra sprawiedliwości. Ustawa stanowiła swoisty kompromis, także o charakterze politycznym, który osiągnięto podczas procesu legislacyjnego. W związku z tym tekst ustawy był pełen reliktów z poprzedniej epoki zapewniających ministrowi sprawiedliwości dyskrecjonalną kontrolę nad Sądem Najwyższym ${ }^{59}$. W rękach ministra sprawiedliwości nadal pozostały liczne uprawnienia $\mathrm{w}$ zakresie spraw kadrowych i organizacji pracy Sądu Najwyższego. Współdziałał z Pierwszy Prezesem w procesie tworzenie prawa regulującego sferę organizacyjną Sądu Najwyższego oraz miał prawo inicjowania określonych działań judykacyjnych Sądu Najwyższego. Podobne uprawnienia w zakresie działania nowo utworzonej Izby Wojskowej Sądu Najwyższego miał minister obrony narodowej ${ }^{60}$.

Ustawa przewidywała cztery izby Sądu Najwyższego. Obok Izby Cywilnej i Izby Karnej utworzone zostały dwie nowe Izby: Wojskowa oraz Pracy i Ubezpieczeń Społecznych ${ }^{61}$. Struktura ta odbiegała od znanych wzorców w krajach tzw. demokracji ludowej. Najczęściej istniejący podział to trzy izby: cywilna, karna i wojskowa (Bułgaria, Czechosłowacja, ZSRR), chociaż pojawiała się niekiedy czwarta izba: transportu (Węgry, Rumunia), administracyjna (Jugosławia) lub dyscyplinarna (Albania). Tym samym utworzenie $\mathrm{w}$ trakcie prac sejmowych Izby Pracy i Ubezpieczeń Społecznych było całkowitą nowością, która stanowiła swoistą cechę odrębności organizacyjnej polskiego Sądu Najwyższego ${ }^{62}$.

Uchwalenie ustawy stanowiło podstawę do wyboru nowego składu Sądu Najwyższego, a w rzeczywistości okazję do przeprowadzenia weryfikacji jego sędziów. Zasady i tryb przeprowadzenia wyborów regulowała Konstytucja PRL, ustawa o Sądzie Najwyższym, a bardziej szczegółowe kwestie zawie-

59 AAN, MS 32, Notatka ministra Rybickiego po konsultacjach z ministrem Walczakiem i dyrektorem Bafią z maja 1961, k. 14-15; MS 409, Zestawienie uwag do projektu ustawy o Sądzie Najwyższym, s. 40, Sekretarz Komisji ds. Wymiaru Sprawiedliwości i Bezpieczeństwa Publicznego do wiceministra sprawiedliwości S. Walczaka z lutego 1961 r., k. 50-51 i M. Rybicki do R. Strzeleckiego Sekretarza KC PZPR [b.d.], k. 17-19; Z. Resich, Sąd Najwyższy w systemie organów wymiaru sprawiedliwości, NP 1982, nr 9-10, s. 37.

60 Art. 14, 15, 17, 20 ust. 2, 28, 29, 36 ustawy o Sądzie Najwyższym z 1962 r.; art. 47 Prawa o ustroju sądów powszechnych; L. Garlicki, Z. Resich, M. Rybicki, S. Włodyka, op. cit., s. 102-103, 126; L. Garlicki, Sąd Najwyższy a naczelne organy władzy państwowej w PRL..., s. 101-102; S. Włodyka, Organizacja wymiaru sprawiedliwości PRL, Warszawa 1963, s. 138-139.

61 Art. 4 ustawy o Sądzie Najwyższym z 1962 r.; Z. Resich, XX-lecie Trybunału Ubezpieczeń Społecznych, NP 1966, Nr 9, s. 1040; F. Rusek, Wymiar sprawiedliwości PRL w budownictwie socjalizmu, [w:] XXV lat wymiaru sprawiedliwości PRL, Warszawa 1969, s. 28; M. Paluch, Sąd Najwyższy PRL, [w:] XXV lat wymiaru sprawiedliwości PRL, Warszawa 1969, s. 160.

62 AAN, MS 409, Notatka o strukturze i zadaniach sądów najwyższych: ZSRR i krajów demokracji ludowej z 26 VIII 1960 r., k. 29-34; A. Gorkin, Usytuowanie Sądu Najwyższego ZSRR w systemie radzieckich organów państwowych, NP 1967, nr 11, s. 1400; Z. Resich, Ustawa o Sądzie Najwyższym, PiP 1962, z. 5-6, s. 774, 776-777; H. Kempisty, Ustrój sądów. Komentarz, Warszawa 1966, s. 13. 
rała uchwała Nr 24/62 Rady Państwa z 22 maja 1962 r. w sprawie ustalenia liczby prezesów i sędziów Sądu Najwyższego oraz sposobu przeprowadzania wyboru tego Sądu' ${ }^{63}$.

Do grona kandydatów na sędziów Sądu Najwyższego I kadencji zaliczono sędziów ówczesnego Sądu Najwyższego i likwidowanego Najwyższego Sądu Wojskowego, a także osoby przedstawiane przez ministra sprawiedliwości, a jeżeli chodzi o Izbę Wojskową - ministra sprawiedliwości w porozumieniu $\mathrm{z}$ ministrem obrony narodowej ${ }^{64}$. Minister sprawiedliwości $\mathrm{w}$ praktyce inicjował postępowanie nominacyjne, przedstawiając Radzie Państwa swoją opinię dotyczącą kandydata. Wybór w 1962 r. ograniczał się do akceptacji osób rekomendowanych przez ministra sprawiedliwości, która była uzależniona od trzech czynników: doświadczenia zawodowego, należytego wykonywania obowiązków sędziowskich i właściwej postawy społeczno-politycznej. Kandydatom stawiano więc wymagania dotyczące „wysokiej świadomości politycznej, umiejętności widzenia zjawisk i zadań, jakie wyrastają w procesie budowy socjalizmu" 65 .

Spośród dotychczasowych sędziów Sądu Najwyższego tylko profesor Uniwersytetu Warszawskiego Stefan Kalinowski nie wyraził zgody na kandydowanie. Spośród pozostałych sędziów Sądu Najwyższego minister sprawiedliwości nie poparł aż 20 kandydatur. Powodem takiego stanowiska był podeszły wiek sędziego (Stefan Breyer, Jan Kamiński, Leon Konic, Kazimierz Kwapiszewski, Marian Lisiewski, Julian Potępa, Witold Święcicki, Franciszek Czesław Tabęcki, Mieczysław Szerer), a także nierówno orzekający (Emil Merz), piastowane funkcje (Jan Pawlak, Stanisław Pławski), cechy osobowościowe (Aleksander Bachrach) czy klerykalizm (Bronisław Dobrzański). Ze względów politycznych odmówiono rekomendacji jednemu sędziemu (Michał Kenigsberg), a drugiemu z uwagi na wykonywanie zawodu adwokata przez członka najbliższej rodziny, co było sprzeczne z dezyderatami sejmowej Komisji Wymiaru Sprawiedliwości (Piotr Stępień). Pojawiały się również zarzuty dotyczące jakości orzecznictwa, co było pochodną wcześniejszej pracy w Komisji Specjalnej lub sądach wojskowych (Mieczysław Dźbikowski, Marian Fic, Antoni Górski) lub poziomu staranności przy wypełnianiu obowiązków sędziowskich (Mieczysław Kulesza) ${ }^{66}$. Dotychczasowa służba w sądach wojskowych nie dyskwa-

63 Art. 3 ust. 1 i 2 ustawy o Sądzie Najwyższym z 1962 r.

64 Art. $50 \mathrm{w}$ związku z art. 17 ustawy o Sądzie Najwyższym z 1962 r.

65 Z przemówienia Przewodniczącego Rady Państwa PRL Aleksandra Zawadzkiego na uroczystości wręczenia prezesom i sędziom Sądu Najwyższego pism o ich wyborze - „Prawo i Życie” 1962, nr 12.

66 AAN, Kancelaria RP 61/62, Wnioski MS z 10 marca, 15 marca, 29 marca, 31 marca, 2 kwietnia, 22 kwietnia, 4 maja, 8 maja 1962 r., k. 207-233; ASN, Akta osobowe 327, k. 43, Nr 338, k. 12, Nr 336, k. 10v-11, Nr 329, k. 28-30, Nr 326, k. 25, Nr 325, k. 37v, Nr 320, k. 41; Nr 321, k. 30, Nr 323, k. 46, Nr 324, k. 31, Nr 330, k. 44, Nr 334, k. 24-25, 43; A. Bereza, Sąd Najwyższy..., s. 318. 
lifikowała kandydatów, gdyż paru sędziów najwyższej instancji sądownictwa wojskowego, znanych z niezwykle surowego orzecznictwa (Józef Dziowgo, Alfred Janowski, Roman Kryże), zostało wybranych do Izby Karnej Sądu Najwyższego ${ }^{67}$.

Do Izby Wojskowej Sądu Najwyższego przedstawiono łącznie 20 kandydatów - sędziów Najwyższego Sądu Wojskowego. Spośród nich, 6 kandydatów (m.in. płk Jan Mitek, ostatni prezes Najwyższego Sądu Wojskowego) nie uzyskało rekomendacji ministra sprawiedliwości w porozumieniu z ministrem obrony narodowej. Przyczyną był brak doświadczenia w pracy sędziego rewizyjnego, przekroczenie wieku 60 lat ( $w$ związku z tym podlegali zwolnieniu z wojskowej służby zawodowej), czy też niewłaściwa linia orzecznictwa w okresie pracy sędziowskiej ${ }^{68}$. Kilku sędziów Najwyższego Sądu Wojskowego uzyskało rekomendację, mimo kontrowersji związanych z ich niezwykle upolitycznionym i surowym orzecznictwem. Wśród nich znaleźli się m.in. płk Kryspin Mioduski i płk Zygmunt Krasuski, wobec których komisja Mazura-Wasilewskiego badająca przypadki łamania praworządności w sądownictwie wojskowym zaleciła w czerwcu 1957 r. przeniesienie do sądu niższego, a także ppłk Jerzy Drohomirecki, płk Zbigniew Furtak, płk Zygmunt Wizelberg oraz płk Józef Badecki ${ }^{69}$.

Pierwszy wybór sędziów Sądu Najwyższego przez Radę Państwa nastąpił 22 maja 1962 r., dokładnie 3 miesiące od wejścia ustawy o Sądzie Najwyższym w życie ${ }^{70}$. Rada Państwa, wybierając skład Sądu Najwyższego jednocześnie wybierała Pierwszego Prezesa oraz prezesów Sądu Najwyższego, ustalając tym samym ich liczbę. Pierwszym Prezesem Sądu Najwyższego został Jan Wasilkowski. Wybrano 5 prezesów, w tym prezesa do spraw ogólnych (Marian Mazur) i 4 kierujących poszczególnymi izbami (Zbigniew Resich, Zygmunt Opuszyń-

67 M. Stanowska, Sprawy polityczne z lat 1944-56 w świetle orzeczeń rehabilitacyjnych Sąu Najwyższego w latach 1988-91, „Studia Iuridica” 1995, nr 27, s. 87; eadem, Orzecznictwo Sądu Najwyższego w sprawach rehabilitacyjnych w latach 1988-1991, „Archiwum Kryminologii" 1993, t. XIX, s. 187-188; eadem, Próby rozliczenia z przeszłością w wymiarze sprawiedliwości, [w:] Ius et lex. Księga jubileuszowa ku czci Profesora Adama Strzembosza, red. A. Dębiński, A. Grześkowiak, K. Wiak, Lublin 2002, s. 315-317; A. Strzembosz, M. Stanowska, Sędziowie warszawscy w czasie próby 1981-1988, Warszawa 2005, s. 22; B. Dzięcioł, Działalność Najwyższego Sądu Wojskowego w 1945 roku, WPP 1986, nr 1, s. $40-41$.

68 Art. 10 ust. 3 i art. 50 ustawy o Sądzie Najwyższym z 1962 r.; art. 55 ust. 1 pkt 2 ustawy z 13 grudnia 1957 r. o służbie wojskowej oficerów Sił Zbrojnych (Dz. U. z 1958 r. Nr 2, poz. 5); AAN, Kancelaria RP 59/9, MS do RP z 9 maja 1962 r., k. 57 i wnioski MS do RP ich dotyczące z 26 marca 1962 r. wraz z powołaniami, k. 58-112; K. Szwagrzyk, Zbrodnie w majestacie prawa 1944-1956, Warszawa 2000, s. 74, 113, 149; W. Sieracki, Z żałobnej karty, WPP 1985, nr 2, s. 248-249.

69 M. Stanowska, Próby rozliczenia..., s. 312; W. Sieracki, Z żałobnej karty, WPP 1986, nr 3, s. 340; K. Szwagrzyk, Zbrodnie w majestacie prawa..., s. 67, 73, 75, 83, 92, 111, 124, 126, 129, 131, 132, 134, $137,144,148$.

70 Art. 50 ustawy o Sądzie Najwyższym z 1962 r. 
ski, Franciszek Wróblewski i płk Kazimierz Jankowski) oraz 80 sędziów Sądu Najwyższego ${ }^{71}$.

Korpus sędziowski Sądu Najwyższego składał się z osób, które zostały zaakceptowane przez odpowiednie komórki organizacji partyjnej na szczeblu centralnym ${ }^{72}$. Rada Państwa ograniczyła się $\mathrm{w}$ wyborze do przedstawionej grupy kandydatów, chociaż w trakcie dyskusji pojawiły się kontrowersje dotyczące jednego z sędziów - Jana Dorsza. Jego kandydatura nie została poparta przez ministra sprawiedliwości, jak przez komisję Rady Państwa opiniującą kandydatów. Związane to było z przeszłością sędziego, który - jak ustalono - $\mathrm{w}$ okresie międzywojennym orzekał $\mathrm{w}$ procesie przeciwko komunistom. Na posiedzeniu Rady Państwa przeważyły jednak jego dotychczasowe zasługi dla wymiaru sprawiedliwości w Polsce Ludowej, tym bardziej że kandydaturę tę w trakcie debaty osobiście poparł Władysław Gomułka ${ }^{73}$.

Po przeprowadzonych wyborach Sąd Najwyższy ukonstytuował się w nowej strukturze organizacyjnej 1 czerwca 1962 r. Do Izby Cywilnej przydzielono - 16, do Izby Pracy i Ubezpieczeń Społecznych - 15, do Izby Karnej - 35 sędziów, zaś do Izby Wojskowej weszło 14 wybranych sędziów wojskowych ${ }^{74}$.

Zgodnie z planami władz politycznych tak ukształtowany Sąd Najwyższy miał być - zwłaszcza przez odnowiony skład Izby Karnej - sądem właściwie przygotowanym do zmiany dotychczasowego orzecznictwa karnego, które miało realizować nową, prawidłową - w oczach partii - linię polityki karnej $^{75}$.

71 AAN, Kancelaria RP 61/62, Wniosek MS z 29 marca 1962 r., k. 3-5; ASN, Dokumenty wyodrębnione, Uchwała RP w sprawie wyboru SN z 22 maja 1962 r., poz. 35. ASN, Akta osobowe Nr 530, nfol.; T. Mołdawa, Ludzie władzy 1944-1991, Warszawa 1991, s. 417.

72 W Wydziale Administracyjnym KC PZPR, który został powołany w celu „umacniania oddziaływania Partii w kierunku pogłębiania praworządności oraz realizacji polityki partii i bardziej skutecznego oddziaływania na politykę kadrową" (AAN, KC PZPR LI 17, Zakres pracy i struktura Wydziału Administracyjnego, nfol.) lub Główny Zarząd Polityczny Wojska Polskiego.

73 T. Sypniewski, Rada Państwa..., s. 315-316; L. Garlicki, Sąd Najwyższy a naczelne organy wtadzy państwowej w PRL..., s. 42.

74 AAN, SN 1/133, KA SN 1962-1967, Dziennik posiedzeń z 1 czerwca 1962 r., k. 2-3 i 4 czerwca 1962 r., k. 5-6; MS 31, Informacja wstępna o działalności Sądu Najwyższego od dnia wyboru w 1962 r., k. 116; ASN, Dokumenty wyodrębnione, Zarządzenie Pierwszego Prezesa SN Nr 29/62 z 1 czerwca 1962 r., nfol.; M. Mazur, W rocznicę ustawy o Sądzie Najwyższym, NP 1963, nr 4-5, s. 407. Przydział sędziów do poszczególnych izb dokonywało przy podziale czynności Kolegium Administracyjne. Nie dotyczyło to Izby Wojskowej Sądu Najwyższego, gdyż sędziowie byli wskazani w powołującej ich uchwale Rady Państwa (§ 9 Regulaminu Sądu Najwyższego z 22 maja 1962 r. - M. P. Nr 45, poz. 210).

75 AAN, MS 409, Pismo do PZPR Zastępcy Kierownika Wydziału Administracyjnego S. Marczewskiego z 20 października 1960 r., k. 49; R. Walczak, Przewodnia rola partii w sqadach powszechnych..., s. $60-61$. 


\section{Bibliografia}

\section{Akty prawne}

Obwieszczenie Ministra Sprawiedliwości z dnia 15 listopada 1932 r. w sprawie ogłoszenia jednolitego tekstu prawa o ustroju sądów powszechnych (Dz. U. Nr 102, poz. 863)

Obwieszczenie Ministra Sprawiedliwości z dnia 16 sierpnia 1950 r. o ogłoszeniu jednolitego tekstu prawa o ustroju sądów powszechnych (Dz. U. z 1950 r. Nr 39, poz. 360)

Konstytucja Polskiej Rzeczypospolitej Ludowej z dnia 22 lipca 1952 r. (Dz. U. z 1952 r. Nr 33, poz. 232)

Rozporządzenie Prezydenta Rzeczypospolitej z dnia 6 lutego 1928 r. - Prawo o ustroju sądów powszechnych (Dz. U. z 1928 r. Nr 12, poz. 93)

Rozporządzenie Ministra Sprawiedliwości z dnia 3 marca 1945 r. o tymczasowej siedzibie Sądu Najwyższego (Dz. U. Nr 7, poz. 35)

Ustawa Konstytucyjna z dnia 22 lipca 1952 r. - Przepisy wprowadzające Konstytucję Polskiej Rzeczypospolitej Ludowej (Dz. U. Nr 33, poz. 233)

Ustawa z dnia 13 grudnia 1957 r. o służbie wojskowej oficerów Sił Zbrojnych (Dz. U. z 1958 r. Nr 2, poz. 5)

Ustawa o Sądzie Najwyższym z dnia 15 lutego 1962 r. (Dz. U. z 1962 r. Nr 11, poz. 54)

Uchwała Rady Państwa z dnia 22 maja 1962 r. w sprawie regulaminu Sądu Najwyższego (M. P. Nr 45, poz. 210)

\section{Źródła}

Archiwum Rodziny Barcikowskich:

Projekt ustawy z 1950 r. o ustroju sądów, redakcja II Leszek Lernell, nfol.

Wspomnienia W. Barcikowskiego z 1952 r., k. 21-22.

Archiwum Akt Nowych

Ministerstwo Sprawiedliwości 31, 32, 229, 409

Sąd Najwyższy 1/132, 1/133,1/154, 1/180, 1/181, 1/199

Komitet Centralny Polskiej Zjednoczonej Partii Robotniczej LI 17, LI 58

Kancelaria RP 59/9, 61/62

Archiwum Sądu Najwyższego:

Dokumenty wyodrębnione, Uchwała RP w sprawie wyboru SN z 22 maja 1962 r., poz. 35; Zarządzenie Pierwszego Prezesa SN Nr 29/62 z 1 czerwca 1962 r., nfol.;

Akta osobowe 327, k. 43, Nr 338, k. 12, Nr 336, k. 10v-11, Nr 329, k. 28-30, Nr 326, k. 25, Nr 325, k. 37v, Nr 320, k. 41; Nr 321, k. 30, Nr 323, k. 46, Nr 324, k. 31, Nr 330, k. 44, Nr 334, k. 24-25, 43; Nr 530, nfol. 
Komunikat w sprawie przeniesienia Sądu Najwyższego od 1 maja 1950 r. do stałej siedziby w Warszawie (Dz. Urz. MS z 1950 r. Nr 3, poz. 11, s. 14)

Biuro Sejmu, Wydział Prasowy, Biuletyn Nr 133 Komisja Wymiaru Sprawiedliwości z 19 grudnia 1961 r., s. 1-3.

Biuro Sejmu, Wydział Prasowy, Biuletyn Nr 137/III kad. Komisja Wymiaru Sprawiedliwości z 5 stycznia 1962 r., s. 1-4;

Konstytucja Polskiej Rzeczypospolitej Ludowej. Projekt uchwalony dnia 23.1.1952 r. przez Komisje Konstytucyjna, PiP 1952, z. 2, s. 196.

Sprawozdanie stenograficzne z 5. posiedzenia Sejmu PRL w dniu 1 grudnia 1961 r. Kadencja III - Sesja II Warszawa 1961, s. 30-33.

Sprawozdanie stenograficzne z 9 posiedzenia Sejmu PRL z dnia 15 lutego 1962 r., Warszawa 1962, ł. 7-18. Nad ustawq o Sądzie Najwyższym (dyskusja w Komitecie Nauk Prawnych PAN nad referatem członka PAN, prof. dr. Jana Wasilkowskiego), (oprac. J. Lapierre), NP 1962, Nr 5, s. 605, 607-608, 612.

\section{Literatura}

A. Bereza, Sąd Najwyższy w latach 1945-1962. Organizacja i działalność, Warszawa 2012.

A. Bereza, Wpływ polskiego Października '56 na organizację i funkcjonowanie Sądu Najwyższego (zarys problematyki), [w:] Społeczeństwo a władza. Ustrój, prawo, idee, red. J. Przygodzki i M. Ptak, Wrocław 2010.

B. Dzięcioł, Działalność Najwyższego Sądu Wojskowego w 1945 roku, „Wojskowy Przegląd Prawniczy" 1986, nr 1.

T. Ereciński, Aktualne problemy ustroju sq̨downictwa, „Państwo i Prawo” 1981, z. 5.

P. Fiedorczyk, Dylematy socjalistycznego kodyfikatora. Dokument archiwalny o pracach Komisji Kodyfikacyjnej w latach 1956-1958, „Miscellanea Historico-Iuridica”, t. VIII, 2009, (przedruk: AAN, MS 545, Przewodniczący Komisji Kodyfikacyjnej przy MS Jan Wasilkowski do wiceministra sprawiedliwości Stanisława Walczaka z 24 VI 1958 r., k. 41-47).

L. Garlicki, Sąd Najwyższy a naczelne organy władzy państwowej w PRL, Warszawa 1977.

L. Garlicki, M. Rybicki, Ustrój sądów w europejskich państwach socjalistycznych, Warszawa 1976.

L. Garlicki, Z. Resich, M. Rybicki, S. Włodyka, Sąd Najwyższy w PRL, Wrocław 1983.

L. Garlicki, Sejm a Sad Najwyższy (Uwagi de lege lata $i$ de lege ferenda), „Państwo i Prawo" 1972, nr 8-9.

A. Gorkin, Usytuowanie Sądu Najwyższego ZSRR w systemie radzieckich organów państwowych, „Nowe Prawo” 1967, nr 11.

S. Guzy, O potrzebie zmian w organizacji sądownictwa wojskowego (Artykut dyskusyjny), „Wojskowy Przegląd Prawniczy” 1962, nr 1.

I. Iserles, Polityka kadr i szkolenia pracowników wymiaru sprawiedliwości w świetle uchwał IV Plenum KC PZPR, DPP 1950, nr 6. 
H. Kempisty, Ustrój sądów. Komentarz, Warszawa 1966.

S. Kotowski, K. Piasecki, Sądy Najwyższe państw socjalistycznych, Warszawa 1988, maszynopis.

J. Kuciński, Ustrojowo-polityczne koncepcje PZPR w latach 1948-1959, Warszawa 1984.

T. Leśko, Uwagi na tle ustawy o Sądzie Najwyższym (głos w dyskusji), „Wojskowy Przegląd Prawniczy" 1962, nr 2.

A. Lityński, Historia prawa Polski Ludowej, Warszawa 2013.

A. Lityński, O praworząności "ludowej” w Polsce 1944-1956 teoretycznych uwag kilka, [w:] Z dziejów prawa, t. 1(8), Katowice 2006.

M. Mazur, Z. Resich, Sąd Najwyższy w okresie XX-lecia Polski Ludowej, „Nowe Prawo” 1964, nr 7-8.

M. Mazur, W rocznicę ustawy o Sądzie Najwyższym, „Nowe Prawo” 1963, nr 4-5.

S. Mendyka, Głos w dyskusji nad potrzeba reformy ustroju sądownictwa wojskowego, „Wojskowy Przegląd Prawniczy” 1962, nr 2.

T. Mołdawa, Ludzie władzy 1944-1991, Warszawa 1991.

M. Paluch, Sąd Najwyższy PRL, [w:] XXV lat wymiaru sprawiedliwości PRL, Warszawa 1969.

J. Polan-Haraschin, $W$ sprawie zmian organizacyjnych w sadownictwie wojskowym (Głos $w$ dyskusji), „Wojskowy Przegląd Prawniczy” 1962, nr 1.

Z. Resich, Ustawa o Sądzie Najwyższym, „Państwo i Prawo” 1962, z. 5-6.

Z. Resich, Pozycja Sądu Najwyższego w PRL, „Nowe Prawo” 1969, nr 4.

Z. Resich, Sąd Najwyższy w systemie organów wymiaru sprawiedliwości, "Nowe Prawo” 1982, nr 9-10.

Z. Resich, XX-lecie Trybunału Ubezpieczeń Społecznych, „Nowe Prawo” 1966, nr 9.

F. Rusek, Wymiar sprawiedliwości PRL w budownictwie socjalizmu, [w:] XXV lat wymiaru sprawiedliwości PRL, Warszawa 1969.

W. Sieracki, Z żałobnej karty, „Wojskowy Przegląd Prawniczy” 1985, nr 2.

M. Stanowska, Sprawy polityczne z lat 1944-56 w świetle orzeczeń rehabilitacyjnych Sądu Najwyższego w latach 1988-91, „Studia Iuridica” 1995, nr 27.

M. Stanowska, Orzecznictwo Sądu Najwyższego w sprawach rehabilitacyjnych w latach 1988-1991, „Archiwum Kryminologii” 1993, t. XIX.

M. Stanowska, Próby rozliczenia z przeszłościa w wymiarze sprawiedliwości, [w:] Ius et lex. Księga jubileuszowa ku czci Profesora Adama Strzembosza, red. A. Dębiński, A. Grześkowiak, K. Wiak, Lublin 2002.

A. Strzembosz, M. Stanowska, Sędziowie warszawscy w czasie próby 1981-1988, Warszawa 2005.

T. Sypniewski, Rada Państwa w systemie organów władzy państwowej Polski Ludowej (1947-1989), Toruń 2010.

B. Szmulik, Sąd Najwyższy w PRL, [w:] W kręu nowożytnej i najnowszej historii ustroju Polski. Ksiegga dedykowana Profesorowi Marianowi Kallasowi, red. S. Godek, D. Makiłła, M. Wilczek-Karczewska, Warszawa 2010. 
K. Szwagrzyk, Zbrodnie w majestacie prawa 1944-1956, Warszawa 2000.

R. Walczak, Sprawowanie kierowniczej roli partii w sadach i prokuraturze w Polsce Ludowej (studium politologiczne), Warszawa 1987.

R. Walczak, Przewodnia rola partii w sadach powszechnych w Polsce Ludowej, [w:] Przewodnia rola partii a niezawisłość sędziowska („Biblioteka Sędziego” nr 58), Warszawa 1987.

Z. Wasilkowska, O potrzebie i kierunkach zmian przepisów o Sądzie Najwyższym, „Nowe Prawo" 1981, nr 4.

S. Włodyka, Funkcje Sądu Najwyższego, „Zeszyty Naukowe UJ” 1965, z. 31.

S. Włodyka, Organizacja wymiaru sprawiedliwości PRL, Warszawa 1963.

„Prawo i Życie” 1962, nr 12.

Z żałobnej karty, „Wojskowy Przegląd Prawniczy” 1985, nr 2, i 1986, nr 3 (oprac. W. Sieracki). 